\title{
カーボンナノチューブの電界電子放出特性とディスプレイ応用†
}

\author{
秋 田成 司* 松 本 昌 司* \\ 村上 明 繁* 中 山喜 萬**
}

\section{Field Emission Properties of Carbon Nanotubes and Its Application to Flat Panel Display}

\author{
by \\ Seiji Akita * , Syoji Matsumoto *, Akisige Murakami * and Yoshikazu NaKayama **
}

\begin{abstract}
We have investigated field emission properties from an individual carbon nanotube protruded $\sim 45 \mu \mathrm{m}$ from a tungsten needle tip. The I-V characteristics of the field emitter show no emitter-collector gap dependence at a gap less than $310 \mu \mathrm{m}$. This experimental result is explained by an analysis under a consideration of the nonuniform electric field near the tip of the nanotube. The tip radius of $2.7 \mathrm{~nm}$, which is obtained from the analysis, is consistent with the average tip radius of nanotubes. The field emission device for a flat panel display consisting of the well perpendicularly aligned carbon nanotube array is fabricated by the catalytic chemical vapor deposition using $\mathrm{C}_{2} \mathrm{H}_{2}$ as source gas. Patterned emission device is easily obtained by patterning the catalyst. The threshold voltage for the field emission decreases from $400 \mathrm{~V}$ to $150 \mathrm{~V}$ by the thermal treatment in air at $700^{\circ} \mathrm{C}$ for $8 \mathrm{~min}$. We also demonstrate that the diode type display consisting of a phosphor coated electrode and the nanotube device emits strong and uniform luminescence.
\end{abstract}

Key words : Carbon nanotube, Electron field emission, Fowler-Nordheim plot, Flat panel display

\section{1.は じめに}

カーボンナノチューブは, 平均的な直径が $10 \mathrm{~nm}$ 前後, 長さが数ミクロンと高いアスペクト比を持ち, さらにそ の先端の曲率半径は非常に小さい. このため, 電界印加 時に执いて，容易に先端付近で高電界が得られる。また， 化学的にも物理的にも非常に安定である。したがって， 従来の電界放出源よりも低真空領域での長寿命化が期待 できる。これらのことからナノチューブは電界放出源と して適した素材として精力的に研究されている.1) -6)

最近, 気相成長法によりその触媒金属をパターニング することで，基板に垂直にかつパターン化したナノチュ

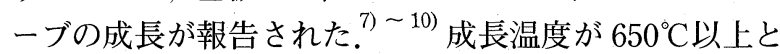
高く安価なガラス基板の使用が困難であるが, 成長と同 時にパターニングが可能で，更に，基板への垂直方向へ の配向度が高いといった利点を有する.

このようなナノチューブ 2 次元電界放出デバイスの特 性向上を目指すためには個々のナノチューブの電子放出 特性を詳しく理解する必要がある。これまでナノチュー ブ電子放出源の特性は多くの場合 Fowler-Nordheim の関 係式で解析されてきた。これに対し，ナノチューブのよ うにアスペクト比が高く先端径の小さい電子放出源先端 部の電界は, 電極間距離に依存せず印加電圧 $V$ と先端の 半径 $\mathrm{r}$ にのみ依存すると理論的に予想される。この場合, 従来の Fowler-Nordheim (F-N) プロットでなく, 正確な
電位分布を考慮して解析する必要がある ${ }^{6)}$ ことを提案し てきたが, 孤立したナノチューブに対する電子放出特性 の距離依存性に関する実験結果の報告はない.

本論文では，これらカーボンナノチューブのフラット パネルディスプレイ用電界放出デバイスへの応用を目的 とし, カーボンナノチューブ電子放出源を解析する上で 必要な理論の提案を行い, 突出したナノチューブに対す る電子放出特性のエミッターコレクタ距離依存性につい て検討した.さらに 2 次元電界電子放出素子を気相成長 により製作し，その特性について検討した。

\section{2 ナノチューブからの電子放出理論}

一般的に平行平板で構成されたダイオード構造の電界 放出特性は次式の Fowler-Nordheim の関係式で説明され る. ${ }^{11)}$

$$
J=A F^{2} / \alpha^{2} \exp \left(-B \phi^{3 / 2} / \alpha F\right)
$$

ただし, $J$ は電流密度, $F$ は局所電界, $\phi$ はエミッターの 仕事関数， $\alpha$ は鏡像効果の補正項， $A$ はエミッターに依 存した定数， $B=6.83 \times 10^{7}\left[\mathrm{eV}^{-3 / 2} \mathrm{Vcm}^{-1}\right]$ である。均一 な電界分布下では, 印加電圧 $V$ と放出電流を FowlerNordheim プロット $\left(J / V^{2}\right.$ vs. $\left.1 / V\right)$ をすると $\phi$ に依存した 傾きを持つ一つの直線となる.

しかし，カーボンナノチューブのように針状構造では 先端付近へ電界が局所的に集中している.ナノチューブ の先端を半球と仮定すると先端における局所電界は

$\dagger$ 原稿受理 平成 12 年 7 月 4 日 Received July 4, 2000

* 大阪府立大学大学院工学研究科電子物理工学分野 干599-8531 堺市学園町, Dept. of Physics and Electronics, Osaka Pref. Univ., Gakuen-cho, Sakai 599-8531

** 正 会 員 大阪府立大学大学院工学研究科電子物理工学分野 † 599-8531 堺市学園町, Dept. of Physics and Electronics, Osaka Pref. Univ., Gakuen-cho, Sakai 599-8531 


$$
F_{0}=V / \beta r
$$

によって与えられる。ただし， $\beta$ は形状因子で 3 から 5 の值を取る. $r$ は先端半径である. 先端周辺の電界は先 端からの距離 $x$ の增加にともなって $F=V r / \beta(r+x)^{2}$ にし たがって減少する。これを基に, WKB 近似から電流電 圧特性を計算すると次式となる。

$$
F_{0}^{2} \exp \left\{-C r\left[\begin{array}{l}
\frac{e V}{\beta(e V-\beta \phi)} \\
\times\left(\frac{\pi}{2}-\sin ^{-1} \sqrt{\frac{e V-\beta \phi}{e V}}\right)-\sqrt{\phi}
\end{array}\right]\right\}
$$

ただし， $C=1.02 \times 10^{8}\left[\mathrm{eV}^{-1 / 2} \mathrm{~cm}^{-1}\right]$ である。式 $(1) \sim(3)$ から計算した結果の F-N プロットを Fig。1 に示す。ここ で, $\beta=5, r=5 \mathrm{~nm}, \phi=4 \sim 5 \mathrm{eV}$ である.式 (3) の結果は 直線ではなく, 高電界側では式 (1) に従うが電界が小さ くなるとそれから外れてくる。数值計算結果は, 実験で 印加する䇩圧の範囲では, 式 (1) に $B=8.0 \times 10^{7}\left[\mathrm{eV}^{-3 / 2}\right.$ $\mathrm{cm}^{-1}$ ] を代入した時の直線とほぼ等価となる。簡単のた めに以下ではこの值を用いて解析を行う。また, 式 (2) より, 先端部の局所電界は印加電圧 $V$ との应に依存す るため, 放出電流密度は, エミッターコレクタ間隔に依 存しない。これより, 単一のナノチューブや, ナノチュ ーブを一次元に配列した線状の放出源に対する放出開始 電圧のエッミターコレクタ間距離依存性が非常に弱いこ とを説明できる。この特性は，デバイス製造時における エッミターコレクタ間距離の精度は, あまり必要でない ことを示している。

\section{3 孤立ナノチューブからの電子放出特性}

\section{$3 \cdot 1$ 実 験}

ナノチューブはアーク放電法により合成した。 ${ }^{12)}$ 放電条 件は, 雲囲気无スにHe を用い, 圧力を 200Torr, 印加 電圧は直流 $20 \mathrm{~V}$, アーク電流密度は $210 \mathrm{~A} / \mathrm{cm}^{2}$ とした。 細い直径分布を得るためにアーク放電空間を冷却した。


孤立したナノチューブ電界電子放出源の製作には, 独

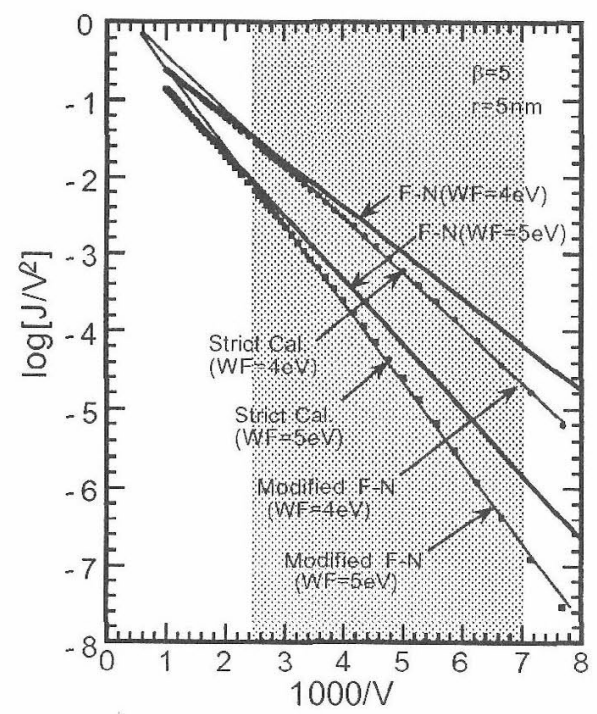

Fig. 1. Fowler-Nordheim plot of calculated results obtained from eqs.(1) and (2).
立した 2 つのマニピュレータを装着した走査型電子顕微 鏡 (SEM) 内で行った. ${ }^{14)}$ Fig. 2 に電解研磨したW 針先端 に笑出長さが約 $45 \mu \mathrm{m}$ のナノチューブ数本のバンドルを 取り付けたナノチューブ電子放出源の SEM 像をホす。 電子放出特性は, 先の SEM 内に就いて圧力 $5 \times 10^{-6}$ Torr, エミッターコレタタ距離 $d$ を $3.8 \mu \mathrm{m} \sim 1.7 \mathrm{~mm}$ と 変化し測定した。ここで，ナノチューブ先端とコレタタ 問の距離は, 電子放出しない程度にバイアス電圧を印加 しナノチューブが静電引力で伂びた状態 (Fig.2(b)) で設 定した。また，この椂に電界印加によりナノチューブの 柔軟性により先端が電界方向に配向することが明らかに なった。

\section{$3 \cdot 2$ 電子放出特性}

Fig. 3 に示すように電極間間隔が $310 \mu \mathrm{m}$ 以下では立 ち上がり開始電厈 $V_{\text {th }}$ は $65 \mathrm{~V}$ 前捘で距離依存性が無く, 電圧依存性もほほ同様である。ただし，立ち上がり開始 電圧は電流が $1 \times 10^{-11} \mathrm{~A}$ の時の印加電圧と定義した。電 極問間隔が $310 \mu \mathrm{m}$ より大きい場合では， $V_{t h}$ は弱い距 離依存性を示す。この様に, 従来の解析で用いられてき
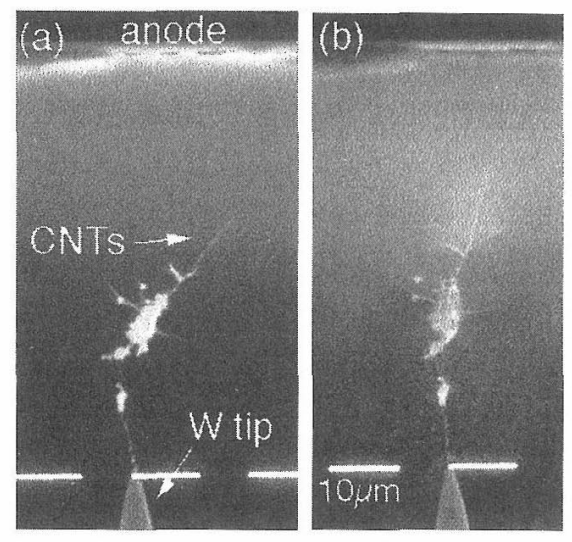

Fig. 2. SEM images of an individual nanotube field emitter, (a) no bias and (b) with bias voltage of $28 \mathrm{~V}$.

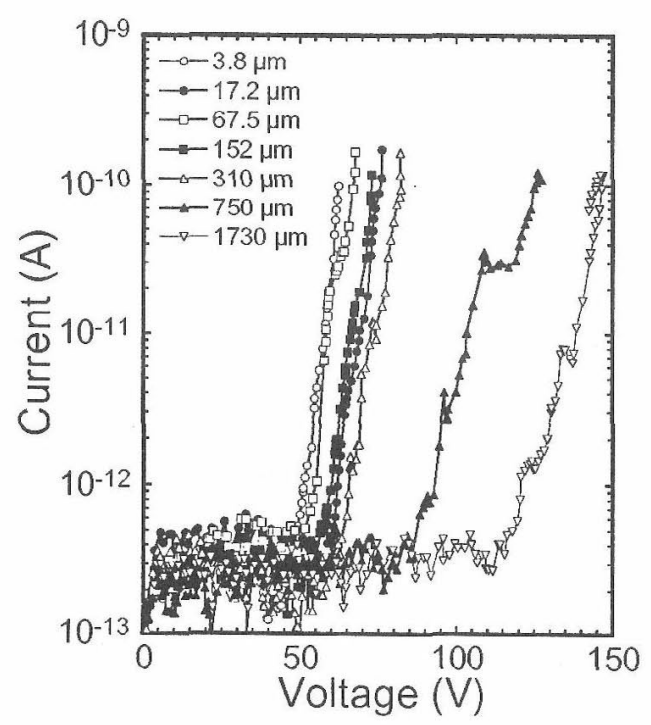

Fig. 3. Electrodes gap dependence of current-voltage characteristics for the individual nanotube field emitter in Fig. 2. 
た平均電界 $(V / d)$ の䓅光方は無意味であり，式 (2)の先 端に於ける局所電界が放出特性を支配していることが分 かる。

これらの特性を Fowler-Nordheim プロットした時, $310 \mu \mathrm{m}$ 以下では，㶢の傾きはほぼ同じとなる。ここで, $\beta=5$, ナノチューブ先端の仕事関数をグラファイトとほ 梁等しい $5 \mathrm{eV}$ とし，この傾きと前節で述べた修正された 補正係数を考慮すると,ナノチューブの先端半径は $2.7 \mathrm{~nm}$ と, 従来報告されている先端径の十数 $\mathrm{nm}$ より小 さくナノチューブの平均的な先端径により近い值となる。 これは,ナノチューブの突出長さが十分長いので電界が ナノチューブ先端付近に効率的に集中するためである. 一方, $310 \mu \mathrm{m}$ より大さい $1.7 \mathrm{~mm}$ の場合では先端径は $6.3 \mathrm{~nm}$ と大きく見積もられる。この領域では電極間間隔 に比べてナノチューブの突出長さが短いためナノチュー ブ先端だけでなくW 針への電界広がりが放出特性に影響 すると考えられる，以上のように，ナノチューブの突出 長さが十分長いとみなせる条件では先端付近の局所電界

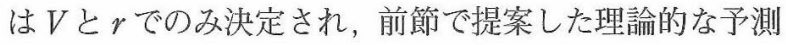
と一致することが明かになった。

\section{4 気相成長ナノチューブ}

\section{$4 \cdot 1$ 実 験}

基板には触媒として Fe を 8～10nm 蒸着した $\mathrm{c}-\mathrm{Si}$ を 用いた。ナノチューブアレイを任意のパターンに成長す るために触媒蒸着膜をパターニングした。ナノチューブ の成長条件は, $\mathrm{C}_{2} \mathrm{H}_{2} / \mathrm{He}=60 / 200 \mathrm{sccm}$, 基板温度 $700^{\circ} \mathrm{C}$, 压力は大気圧, 成長時間は 15 分とした。電界電 子放出の測定は前節と同様の条件で行った。

Fig. 4 に垂直唒向したナノチュープの SEM 像を示す. ナノチューブは基板に刘してほぼ垂值に配向し $45 \mu \mathrm{m}$ 成 長していることがわかる。個々のナノチューブの平均直 径は $24 \mathrm{~nm}$ とアーク版電法で成長したナノチューブのほ ぼ2倍の直径となった。ただし，ナノチューブの成長状 態は基板温度によって大きく変化する，成長時間を長く してもある一定以上の長さには成長せず，ナノチューブ アレイの表面付近にアモルファスカーボンと思われる層 が成長する。これは，ナノチューブが一定長さ以上成長 すると基板表面上の触樂金属への原料为スの効率的空供 給が妨げられ，熱分解した前駆体が，ナノチューブ表面 に吸着，堆積するためと考朰れる。

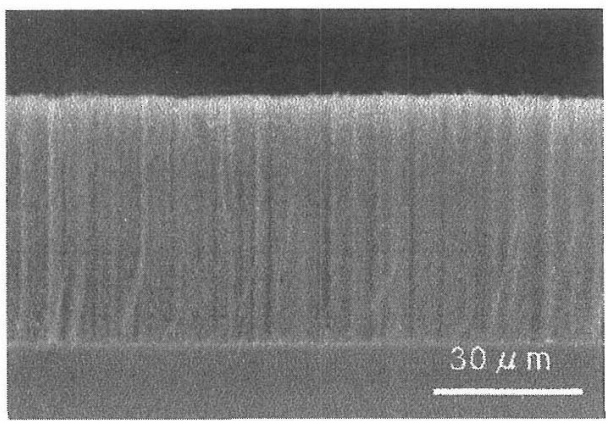

Fig. 4. SEM image of well aligned nanotube.

\section{$4 \cdot 2$ 電子放出特性}

Fig. 5 にナノチューブアレイからの電界電子放出特性 を示す，特に処理を行わない場合は放出開始電圧は $400 \mathrm{~V}$, 電流密度は印加電圧 $900 \mathrm{~V}$ でー $5 \mathrm{~mA} / \mathrm{cm}^{2}$ である。 大気中 $700^{\circ} \mathrm{C}, 8$ 分間熱处理を行うと放出特性は大きく 変化し，放出闑始電圧が〜 $150 \mathrm{~V}$ と著しく低下すること ができた。

Fig. 6 に Fowler-Nordheim プロットを示す。ナノチュ ーブ先端付近の仕事関数を $5 \mathrm{eV}$ とし，第 2 節で述べた関 係を用い，只の傾きから先端部分の半径を見積もった。 酸化前は $17 \mathrm{~nm}$, 酸化後は $5 \mathrm{~nm}$ と電界電子放出に寄与寸 る害効的な先端半径が小さくなることを示している。酸 化处理前後の SEM 観察からナノチューブ構造よりも棈 造的に不安定な先端付近のアモルファスカーボン層が優 先的に酸化・除去され，実効的なナノチューブ先端半径 が減少したことが分かった。このため Fig. 5 に示した電

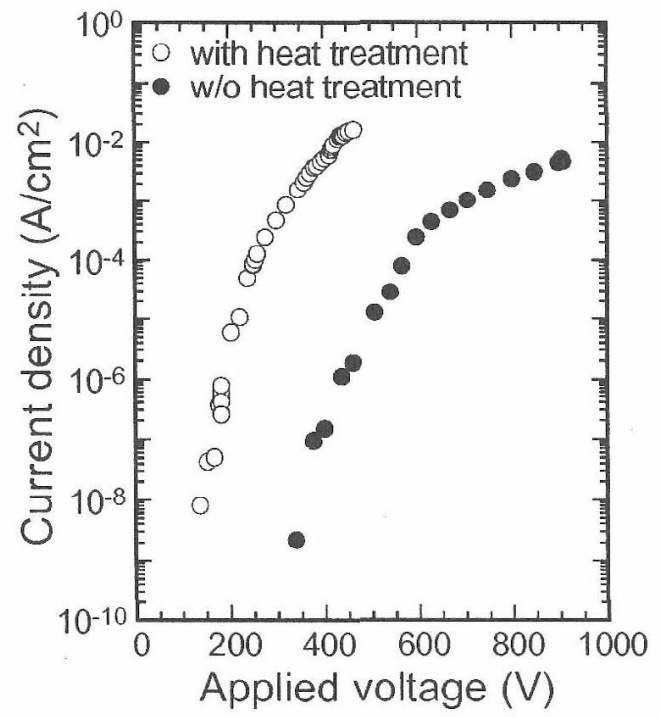

Fig. 5. Electron emission properties of a nanotube array grown by CVD method.

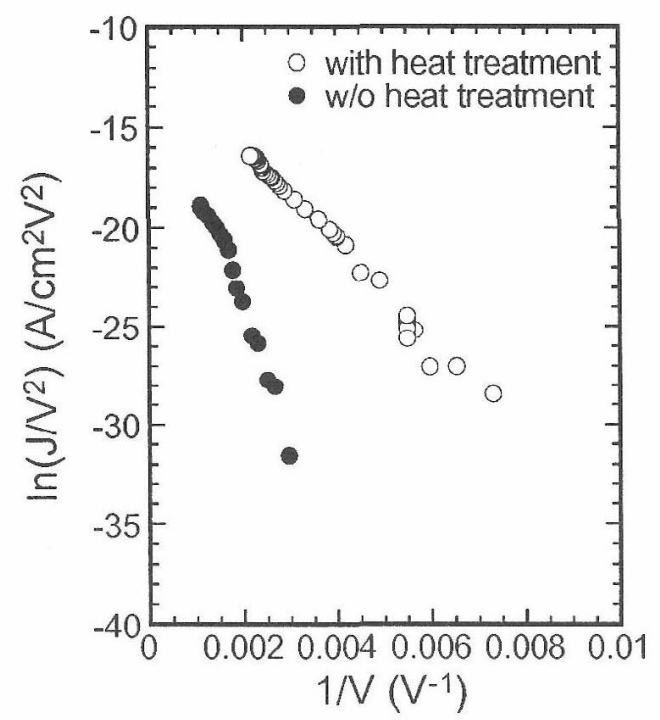

Fig. 6. Fowler-Nordheim plot of I-V curves in Fig. 5. 
子放出開始電厷の低卜が実現できたと思われる。

Fig. 7 に触媒金属をパターニングし成長したナノチュ ーブアレイの SEM 像を示す。触媒金属のパターンに従 ってナノチューブが成長していることが分かる。配向度 が低く成长密度が低いナノチューブアレイを用い発光デ バイスを試作した。Fig.8に示すように文字の全面から 均、に電子が放出されていることが分かる。このように， 垂直に配向しないランダムに成長したナノチューブアレ イからでも容易に面で均一な電子放出を実現できた。さ らなるデバイス性能の向上のためには，垂直に配向し且 つ電界電子放出に適したナノチューブの密度を制御する ことが重要である。

以上のように，気相成長のナノチューブアレイは非常 に優れた特性を示すが, 成長温度 $650^{\circ} \mathrm{C}$ 以上と高いため に更なる成長温度の低下と成長密度の制御が今後の大き な課題である。



Fig. 7. SEM image of a patterned nanotube array grown by CVD method.



Fig. 8. Optical emission pattern from a nanotube array grown by CVD method.

\section{5 ま め}

カーボンナノチューブのように高いアスペクト比を持 つ電子放出源に対し, 先端付近の局所電界分布を正磪に 考虑した理論的解析法を提案した。突出したナノチュー ブに対する電子放出特性から，先端付近の局所電界が解 析のモデル通り距離に依存しないことが明らかになった。 従って，ナノチューブ放出源の様にアスペクト比の高い 放出源では提案した理論でその特性を解析しなければな らないことが明らかになった。さらに熱 CVD 法により 製作した 2 次元電界電子放出素子では，その触媒金属の パターン化でナノチューブアレイが容易にパターニング できること，さらに，大気中熱処理により放出開始電圧 を著しく低下できることを示した。さらに㝢光体を塗布 したコレクタ電極で棈成した発光デバイスを試作し，兄 の動作を確認した。

\section{参考文 献}

1) Q. H. Wang, T. D. Corrigan, J. Y. Dai and R. P. H. Chang, Appl. Phys. Lett., 70, 3308 (1997).

2) P. G. Collins and A. Zettl, Appl. Phys. Lett., 69, 1969 (1996).

3) W. A. de Heer, A. Chatelain and D. Ugarte, Science, 270, 1179 (1995).

4) S. Akita, K. Yamamoto, Y. Yamaguchi and Y. Nakayama, Proceedings of IUMRS-ICA-97 Symposium I Super Carbon, 81 (1998).

5) Y. Nakayama and S. Akita, Proceedings of Pan-Pacific Imaging Conf./ Japan Hardcopy '98, 313 (1998).

6) Y. Nakayama and S. Akita, J. Conducting polymers and Molecular Metals, (to be published).

7) S. S. Fan, M. G. Chapline, N. R. Franklin, T. W. Tombler, A. M. Cassell and H. J. Dai, SCIENCE, 283, 512 (1999).

8) W. Z. Li, S. S. Xie, L. X. Qian, B. H. Chang, B. S. Zou, W. Y. Zhou, R. A. Zhao and G. Wang, Science, 274, 1701 (1996).

9) X. P. Xu and G. R. Brandes, Appl. Phys. Lett., 74, 2549 (1999).

10) S. M. Huang, L. M. Dai and A. W. H. Mau, J. Phys. Chem., B 103, 4223 (1999).

11) R. H. Fowler and L. W. Nordheim, Proc. R. Soc. London, Ser. A 119, 173 (1928).

12) T. W. Ebbesen and P. M. Ajayan, Nature, 358, 220 (1992).

13) Y. Nakayama, S. Akita and Y. Shimada, Jpn. J. Appl. Phys., 34, L10 (1995).

14) H. Nishijima, S. Kamo, S. Akita, Y. Nakayama, K. I. Houmura, S. H. Yoshimura and K. Takeyasu, Appl. Phys. Lett., 744061 (1999). 